\begin{tabular}{|lcl|}
\hline & TOTOBUANG & \\
\hline Volume 6 & Nomor 1, Juni 2018 & Halaman $109-123$ \\
\hline
\end{tabular}

\title{
HOMONIM BAHASA KEPULAUAN TUKANG BESI DIALEK KALEDUPA DI KABUPATEN WAKATOBI \\ (The Homonymon of Tukang Besi Island languange in Kaledupa Dialect at Wakatobi Regency)
}

\author{
Susiati \\ Universitas Iqra Buru
}

Jl. Prof. Dr. H. A.R. Basalamah No. 20, Namlea, Buru

Pos-el: kaledupa123@gmail.com

(Diterima: 30 April 2018; Direvisi 30 Mei 2018; Disetujui: 3 Juni 2018)

\begin{abstract}
This study aimed to describe the form of word classes that was deeply conformed in the Tukang Besi Island languange, Kaledupa dialect at Wakatobi Regency. This research method was qualitative descriptive method. The data source was taken from the native speakers of Tukang Besi Island language, Kaledupa dialect and it was in oral data. Methods and techniques of data collection were observation methods with participantive observation techniques, recording, and noting techniques. Data analysis techniques were data selection, data classification, meaning, and data analysis. The results proved that the form ofhomonimic word class in Tukang Besi Island languange, Kaledupan dialect were adjectives with nouns, nouns with nouns, verbs with adjectives, verbs with nouns, nouns with numerals, verbs with verbs, verbs with adverbs, particles with nouns.

Keywords: form, homonym, kaledupa language
\end{abstract}

\begin{abstract}
Abstrak
Penelitian ini bertujuan untuk mendeskripsikan wujud kelas kata yang berhomonim dalam Bahasa Kepulauan Tukang Besi Dialek Kaledupa di Kabupaten Wakatobi. Metode yang digunakan adalah metode deskriptif kualitatif. Sumber datanya diambil dari para penutur asli bahasa Kepulauan Tukang Besi Dialek Kaledupa dan jenis datanya berupa data lisan. Metode dan teknik pengumpulan data, yaitu metode observasi dengan teknik observasi partisipatif, teknik rekam, dan teknik catat. Teknik analisis data, yaitu penyeleksian data, pengklasifikasian data, pemaknaan, dan penganalisisan data. Hasil penelitian membuktikan bahwa wujud kelas kata yang berhomonim dalam bahasa Kelupauan Tukang Besi Dialek Kaledupa, yaitu adjektiva dengan nomina, nomina dengan nomina, verba dengan adjektiva, verba dengan nomina, nomina dengan numeralia, verba dengan verba, verba dengan adverbia, dan partikel dengan nomina.
\end{abstract}

Kata-kata Kunci: wujud, homonim, bahasa kaledupa

\section{PENDAHULUAN}

Bahasa digunakan untuk berbagai aktivitas dan kepentingan dalam kehidupan sehari-hari. Begitu pula dengan makna bahasa tersebut terlihat beragam dari segi pandangan yang berbeda-beda. Bahasa sering ditemukan relasi makna. Relasi makna dalam bahasaIndonesia meliputi homonim dan polisemi. Kedua relasi makna ini sangat berkaitan dengan kata atau frasa. Relasi makna artinya hubungan semantik yang terdapat antara satuan bahasa yang satu dengan satuan bahasa yang lainnya. Satuan bahasa dapat berupa kata, frasa maupun kalimat dan relasi semantik itu dapat menyatakan kesamaan makna.
Pertentangan makna, ketercakupan makna, kegandaan makna atau juga kelebihan makna.

Chaer dan Agustina (1995:82) mengungkapkan bahwa dalam relasi makna biasanya dibicarakan sinonim, antonim, homonimi, polisemi, hiponimi, ambiguitas, dan redundansi.

Dalam berkomunikasi sering ditemukan kata-kata yang memiliki tulisan dan pelafalan yang sama tetapi makna dari kata-kata tersebut berbeda. Dalam berkomunikasi bisa saja terjadi kesalahpahaman pada pihak lawan bicara, yang disebabkan oleh kekeliruan si 
pembicara dalam mengungkapkan sesuatu hal yang ingin disampaikan. Untuk menghindari terjadinya kesalahpahaman tersebut, maka dalam berbahasa kita harus mengetahui makna atau arti dari kata tersebut. Fenomena ini biasa disebut dengan homonimi.

Homonimi merupakan salah satu kajian dalam semantik. Aminuddin (2008:124) memaparkan bahwa homonimi ialah beberapa kata yang memiliki bentuk ujaran yang sama, tetapi memiliki makna berbeda-beda. Keraf (2009:36) memberikan definisi singkat bahwa homonimi adalah dua kata atau lebih, tetapi memiliki bentuk yang sama.

Homonimi bukan hanya terdapat dalam bahasa Indonesia, tetapi terdapat pula dalam bahasa Daerah. Sutedi (2003) mengemukakan bahwa setiap bahasa daerah sering ditemukan hubungan antarmakna atau relasi semantik antara sebuah kata atau satuan bahasa lainnya. Semantik memegang peranan penting dalam berkomunikasi karena bahasa memiliki fungsi dan tujuan untuk digunakan dalam berkomunikasi dalam menyampaikan suatu makna. Seperti seseorang yang menyampaikan suatu ide dan pikiran kepada lawan bicara, lalu lawan bicara mampu untuk memahami apayang disampaikan.

Keberagaman bahasa daerah di Indonesia merupakan warisan turun temurun oleh nenek moyang kita. Hal tersebut tercantum dalam Undang-Undang Republik Indonesia Nomor 24 Tahun 2009 pada Bab 1, pasal 1, ayat 6 yang berbunyi "Bahasa daerah adalah bahasa yang digunakan secara turun temurun oleh warga negara Indonesia di daerah-daerah di wilayah Negara Kesatuan Republik Indonesia”. Bahasa daerah perlu dilestarikan. Anjuran ini tertuang dalam Undang-Undang Republik Indonesia Nomor 24 Tahun 2009 pada Bab III, pasal 42, ayat 1 yang berbunyi "Pemerintah daerah wajib mengembangkan, membina, dan melindungi bahasa dan sastra daerah agar tetap memenuhi kedudukan dan fungsinya dalam kehidupan bermasyarakat sesuai dengan perkembangan zaman dan agar tetap menjadi bagian dari kekayaan budaya Indonesia". Oleh karena itu, bahasa daerah dan kekayaan budaya harus dijagadan dikembangkan agar tidak mengalami kepunahan.

Fenomena homonimi terlihat pula dalam bahasa Kepulauan Tukang Besi Dialek Kaledupa. Keberagaman kosakata dalam bahasa Kepulauan Tukang Besi Dialek Kaledupa memperlihatkan fungsinya sehingga memungkinkan setiap orang untuk menyesuaikan dirinya dengan lingkungan fisik dan lingkungan sosial yang memungkinkan setiap orang untuk mempelajari kebiasaan, adat istiadat, kebudayaan serta latar belakang masingmasing. Bahasa Kepulauan Tukang Besiadalah bahasayang digunakan oleh masyarakat di Kabupaten Wakatobi. Kabupaten Wakatobi merupakan akronim dari empat gugus pulau,yaitu Pulau WangiWangi, Pulau Kaledupa, Pulau Tomia, dan Pulau Binongko. Bahasa Kepulauan Tukang Besi merupakan bahasa yang digunakan oleh penduduk asli Wakatobi. Bahasa tersebut merupakan bahasa pertama atau bahasa Ibu. Kedudukan bahasa Wakatobi sangat penting dalam kehidupan masyarakat Wakatobi karena dominan masyarakatnya masih kental menggunakan bahasa Ibu mereka. Penggunaan bahasa Wakatobi selalu dijumpai penggunaannya dalam ranah keluarga, lingkungan masyarakat, maupun lingkungan kerja (sekolah dan kantor).

Suku Wakatobi adalah suatu suku asli yang terdapat di Kabupaten Wakatobi Sulawesi Tenggara. Suku Wakatobi mencapai persentase $90 \%$ dari total jumlah penduduk Kabupaten Wakatobi sebesar 90.000 orang. Suku Wakatobi hampir seluruhnya adalah pemeluk agama Islam.Agama Islam masuk ke dalam kalangan suku Wakatobi diperkirakan sejak beberapa abad yang lalu. Terlihat dengan berdirinya bangunan-bangunan masjid dan musala di desa-desa pemukiman suku Wakatobi.

Bahasa Kepulauan Tukang Besi Dialek Kaledupa memperlihatkan fenomena homonimi, yaitu terdapat kata yang berkelas 
kata verba berhomonimi dengan kata yang berkelas kata nomina, nomina dengan nomina, adjektiva dengan adverbia dan sebagainya.

Salah satu contoh temuan dalam penelitian ini adalah kata verba $h u^{\prime} u$ (beri) berhomonim dengan nomina $h u$ 'u (pohon). Contoh dalam kalimat adalah

a. Uhu'u te ye'e? (kamu beri untuk siapa?)

b. Hu'u nu kau iso no tobangkamo (pohon kayu itu sudah tumbang)

Kedua contoh kalimat di atas terlihat adanya kata yang tulisan dan pelafalannya sama, tetapi maknanya berbeda. Kata $h u$ 'u pada kedua kalimat di atas bersifat dua arah.Kalimat pertama yang ditandai dengan kata $h u$ 'u merupakan kelas kata verba yang bermakna "beri", sedangkan kalimat kedua ditandai pula dengan kata $h u$ 'u merupakan kelas kata nomina yang bermakna "pohon". Kehomoniman suatu kata merupakan hal yang sah. Artinya, kesamaan tulisan dan pelafalan suatu kata adalah hal yang dialami juga oleh bahasa-bahasa lain. Makna suatu kata yang berhomonimi akan terlihat setelah disisipkan dalam suatu kalimat dengan konteks yang berbeda-beda.

Penelitian ini bertumpu pada pengategorian wujud kelas kata yang berhomonimi dalam bahasa Kepulauan Tukang Besi Dialek Kaledupa di Kabupaten Wakatobi.

Sudah banyak literatur khusus tentangbahasa Kaledupa, sehingga dapat menunjang peneliti untuk meneliti topik lain yang berkaitan dengan bahasa Kepulauan Tukang Besi Dialek Kaledupa.Beberapa penelitian yang relevan dengan penelitian ini, yakni Rafiati (2016) "Preposisi Bahasa Kepulauan Tukang BesiDialek Kaledupa"; Wa Ode Salmiani Nur (2015) "TipetipeSemantik Bahasa Kepulauan Tukang Besi Dialek Kaledupa. Nadir La Djamudi (2009) "Deskripsi Fonem Bahasa Keledupa di Kepulauan Tukang Besi Kabupaten Wakatobi" dan "Sistem Reduplikasi Bahasa
Kepulauan Tukang Besi Dialek Kaledupa Kabupaten Wakatobi" (2017).

Berdasarkan uraian di atas, maka fokuspenelitian ini adalah bagaimanakah wujud kelas kata yang berhomonimi dalam bahasa Kepulauan Tukang Besi Dialek Kaledupa Kabupaten Wakatobi? Tujuan penelitian ini bertujuan untuk mendeskripsikan wujud kelas kata yang berhomonimi dalam bahasa Kepulauan Tukang Besi Dialek Kaledupa Kabupaten Wakatobi.

Manfaat yang diharapkan dari hasil penelitian ini adalah sebagai berikut (1) Sebagai sarana pemahaman masyarakat terhadap kata-kata yang berhomonimi di Pulau Kaledupa demi pelestarian dan pemertahanan bahasa daerah Kepulauan Tukang Besi Dialek Kaledupa; (2)Sebagai alat atau media sosialisasi dalam upaya pembinaan dan pengembangan Bahasa Kepulauan Tukang Besi Dialek Kaledupa pada masyarakat Pulau Kaledupa.

\section{LANDASAN TEORI Semantik}

Semantik memegang peranan penting dalam berkomunikasi. Disebabkan bahasa memiliki fungsi dan tujuan untuk digunakan dalam berkomunikasi dalam menyampaikan suatu makna (Sutedi, 2003:2). Seperti seseorang yang menyampaikan suatu ide dan pikiran kepada lawan bicara, lalu lawan bicara mampu untuk memahami apa yang disampaikan.

\section{Relasi Makna}

Relasi makna artinya hubungan semantik yang terdapat antara satuan bahasa yang satu dengan satuan bahasa lainnya.Satuan bahasa dapat berupa kata, frasa, maupun kalimat; dan relasi semantik itu dapat menyatakan kesamaan makna. Relasi makna biasanya dibicarakan antara lain sinonim, antonim, polisemi, homonimi, hiponimi, ambiguiti, dan redundansi (Suparmin, dkk, 2014).

Dalam relasi makna ditemukan dua istilah, yakni homonim dan polisemi. Kedua istilah tersebut sering ditumpahtindihkan 
pengertiannya. Padahal, kedua istilah tersebut sangat berbeda. Untuk itu, pemahaman pengertian dan teori dari homonimi dan polisemi sangat penting. Berikut ini akan dibahas pengertian dan teori homonimi dan polisemi.

\section{Homonimi}

Kata homonimi berasal dari bahasa Yunani yang terdiri dari kataanoma berarti "nama" dan homo berarti "sama".Secara harfiah nama sama untuk benda atau hal lain. Jadi, homonimi adalah dua kata atau lebih yangsama nama, sama bunyi, tetapi berbeda makna.

Suparmin dkk (2014) mengungkapkan bahwa homonimi adalah pertalian dua kata atau lebih yang memiliki makna yang berbeda, tetapi pelafalan dan penulisannya sama. Sama halnya juga dengan Djajasudarma (2009) yang mengatakan bahwa homonimi adalah hubungan makna dan bentuk bila dua buah makna atau lebih dinyatakan dengan sebuah bentuk yang sama.

Wijono (2007) mengungkapkan bahwa homonimi adalah dua kata atau lebih yang sama nama, sama bunyi, sebunyi, tetapi berbeda makna. Di dalam kamus katakata yang termasuk homonimi muncul sebagai lema (entri) yang terpisah. Contoh penulisan kata baku dalam kamus.

${ }^{1}$ ba.ku $n$ pokok (bahan baku)

${ }^{2}$ ba.kuv saling (baku hantam)

\begin{tabular}{|c|c|c|}
\hline Kata & Makna 1 & Makna 2 \\
\hline Baku & $\begin{array}{l}\text { Pokok (bahan } \\
\text { baku) }\end{array}$ & $\begin{array}{l}\text { Saling (baku } \\
\text { hantam) }\end{array}$ \\
\hline
\end{tabular}

Hubungan antara dua kata yang berhomonimi bersifat dua arah. Atinya, jika kata baku yang berarti 'pokok (bahan baku)' berhomonimi dengan kata baku yang berarti 'saling (baku hantam)' juga berhomonimi dengan kata baku yang berarti 'pokok (bahan baku)'. Jika kata baku yang berarti 'pokok (bahan baku)' disebut baku I dan kata baku yang berarti 'saling (baku hantam)' disebut $b a k u$ II, diagramnya sebagai berikut.

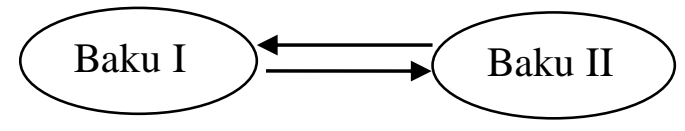

Kata baku pada contoh di atas mempunyai ejaan dan ucapannya yang sama. Akan tetapi, kedua kata tersebut mempunyai makna yang berbeda. Dari contoh tersebut dapat disimpulkan bahwa homonimi adalah dua kata atau frasa yang ejaan atau lafalnya sama, tetapi maknanya berbeda.

Hal tersebut dipertegas pula oleh Suparni (1988) yang menjelaskan bahwa homonimi adalah beberapa kata yang masing-masing mengandung arti sendiri tetapi secara kebetulan sama bentuknya, hanya etimologinya berbeda (sumber berbeda). Secara semantik Verhaar (1978:137) memberikan definisi homonimi sebagai ungkapan (berupa kata, frasa, atau kalimat), tetapi maknanya tidak sama.

Homonimi adalah dua ujaran kata yang sama bunyi dan sama ejaannya, yang telah diketahui berasal dari sumber bahasa yang berbeda atau berbeda bidang makna. Analisis homonimi harus bersifat singkronis, maksudnya bersangkutan dengan peristiwa yang terjadi dalam suatu masa terbatas atau tertentu dan tidak mengakibatkan perkembangan historis atau disebut juga deskriptif.

Di samping itu, ada pula homonimiyang mengenal istilah homofoni (lafal) dan homografi (tulisan), biasanya istilah tersebut dibicarakan bersama karena kesamaan objek pembicaraannya.

Homofoni sebenarnya sama dengan istilah homonimi karena realisasi bentukbentuk bahasa adalah berupa bunyi. Jadi kata 'bisa' yang berarti 'racun ular' dan kata 'bisa' yang berarti 'dapat atau sanggup' selain merupakan bentuk yang homonimi adalah juga bentuk homofoni dan juga homografi karena tulisannya juga sama (Chaer, 1994). Kata-kata yang berhomonimi merupakan kata-kata yang berlainan yang kebetulan saja bentuknya sama. Oleh karena itu, maknanya juga tidak sama. Contohnya kata "buku" yang berarti "kitab" dengan kata "buku" yang berarti "ruas pada bambu 
(tebu), dan juga kata 'buku'yang berarti "tulang atau persendian." Semua itu mempunyai makna yang berbeda-beda, meskipun bentuk dan ucapannya sama.

Untuk dapat mengidentifikasi homonimi dapat dilakukan dengan beberapa cara, yaitu:

1. Pahami etimologi atau asal muasal kata

2. Pahami konteks pemakaian kata/prinsip perluasan kata

3. Pahami makna dasar atau makna inti dari kata. berikut.

Adapun ciri-ciri homonimi sebagai

1. Berupa dua kata atau lebih

2. Tidak ada hubungan makna

3. Digunakan secara denotatif

\section{Jenis-jenis Homonim}

\section{a. Homofon}

Homofon artinya pertalian antara dua kata atau lebih yang sama pengucapannya, tetapi maknanya berbeda.

Contoh:

(1) Bang Ali baru saja menyimpan uangnya di bank.

(2) Hakim menjadi sangsi untuk memberikan sanksi kepada terdakwa.

\section{b. Homograf}

Homograf adalah pertalian antara kata-kata yang memiliki kesamaan tulisan, tetapi berbeda dalam pengucapan dan makna yang terkandung.

Contoh:

(1) Setelah makan buah apel, Arjuna langsung berangkat apel di lapangan.

(2) Pejabat teras itu sedang membaca Koran di teras.

\section{Polisemi}

Dalam kasus ini biasanya makna pertama (yang didaftarkan di dalam kamus) adalah makna sebenarnya, makna leksikalnya, makna denotatifnya, atau makna konseptualnya. Yang lain adalah makna-makna yang dikembangkan berdasarkan salah satu komponen makna yang dimiliki kata atau makna satuan ucap. Polisemi berkaitan dengan kata atau frasa yang memiliki beberapa makna yang berhubungan. Di dalam penyusunan kamus, kata yang berhomonimi muncul sebagai lema (entri) yang terpisah, sedangkan kata yang berpolisemi muncul sebagai satu lema, tetapi dengan beberapa penjelasan.

Contoh kata kepala dapat diartikan bermacam-macam walaupun arti utama kepala adalah bagian tubuh manusia yang ada di atas leher. Contohnya kata kepala dalam Kamus Besar Bahasa Indonesia muncul sebagai satu lema, tetapi dengan beberapa penjelasan seperti berikut.

Ke.pa.la $n^{1}$ bagian tubuh dari leher ke atas seperti pada manusia atau hewan

${ }^{2}$ pimpinan atau ketua

${ }^{3}$ bagian dari sesuatu yang terletak di atas atau depan yang merupakan bagian yang terpenting atau utama

Perhatikan contoh penggunaan kata kepala dalam kalimat.

(1) Kepala sekolah akan memimpin rapat komite

(2) Kepala adik terbentur tembok

(3) Kepala kerta tu sudah tampak tua

Kata kepala pada contoh (1), (2), dan (3) memiliki makna yang berbeda.Pada contoh (1) kata kepala bermakna pimpinan atau ketua. Pada contoh (2) kata kepala bermakna bagian tubuh dari leher ke atas seperti manusia atau hewan. Pada contoh (3) kata kepala bermakna bagian dari sesuatu yang terletak di atas atau depan yang merupakan bagian yang terpenting atau utama.

Polisemi adalah istilah untuk penggunaan dua kata atau lebih yang memiliki bentuk yang sama, tetapi masih memiliki hubungan makna.Polisemi berbeda dengan homonimi, polisemi digunakan secara konotatif (kecuali kata induknya).

Adapun ciri-ciri Polisemi sebagai beikut:

1. Berasal dari satu kata

2. Ada hubungan makna 
3. Digunakan secara konotatif kecuali kata induknya

Aminudin (2008) dalam bukunya 'Semantik' mengambil pendapat Ullman mengenai unsur yang menyebabkan terjadinya polisemi, yaitu (1) spesifikasi dalam ilmu pengetahuan; (2) spesialisasi pemakaian dalam kehidupan sosialmasyarakat yang beraneka ragam;(3) pemakaian dalam gaya bahasa; dan (4) dalam tuturan lisan maupun penulisan yang salah.

\section{Perbedaan Homonimi dan Polisemi}

Perbedaan homonimi dan polisemi terlihat dari pengertian dan ciri-cirinya yang telah diulas sebelumnya. Dua relasi makna tersebut kadang-kadang menimbulkan masalah dalam pemaknaan. Parera (1990) mengatakan bahwa masalah yang muncul dalam relasi makna homonimi dan polisemi adalah kapan dikatakan atau ditentukan dua kata berhubungan secara homonimi dan kapan dua kata itu masuk dalam relasi polisemi.

Perlu diketahui bahwa homonimi dan polisemi tumbuh oleh faktor kesejarahan dan faktor perluasan makna (Djajasudarma, 2009). Jadi keduanya tumbuh sesuai dengan perkembangan masyarakat bahasa itu sendiri. Keduanya memiliki hubungan yang sangat erat karena polisemi dapat saja menjadi penyebab terjadinya homonimi atau sebaliknya homonimi justru menyebabkan adanya polisemi (Aminudin, 2008).

Homonimi ialah dua ujaran dalam bentuk kata yang sama lafalnya dan atau sama ejaannya/tulisannya. Polisemi adalah satu ujaran dalam bentuk kata yang mempunyai makna berbeda-beda, tetapi masih ada hubungan dan kaitan antara makna-makna yang berlainan tersebut (Parera, 1990).

Sebagaimana telah diungkapkan masalah homonimi dan polisemi di atas, adapula masalah yang tengah dihadapi dalam membedakan kedua relasi makna tersebut, yakni bagaimana cara menentukan bahwa satu bentuk ujaran dalam bentuk kata merupakan homonim (jadi seharusnya dua kata) atau merupakan satu kata dengan makna lebih dari satu, tetapi masih berhubungan. Studi tentang hubungan dan perbedaan antara homonimi dan polisemi menuntut studi semantik secara historis (diakronis) dan studi semantik secara sinkronis (Parera, 1990).

Jika dua ujaran kata yang sama bunyinya dan atau sama ejaannya telah diketahui berasal dari sumber bahasa yang berbeda, maka dua kata yang ejaan dan lafalnya sama itu disebut homonimi. Ini berarti jika melakukan satu studi semantik secara historis. Misalnya, kata buku dalam bahasa Indonesia masih dapat dibedakan atas dua sumber asal, maka dapat dikatakan ada homonim: 'buku I' adalah kata Indonesia asli bermakna 'tulang sendi; bagian yang keras pada pertemuan dua ruas' dan 'buku II' yang berasal dari bahasa Belanda yang bermakna 'beberapa helai kertas yang telah terjilid untuk ditulisi atau telah berisi tulisan'.

Palmer (1990) memberikan beberapa kemungkinan jawaban tentang apakah ujaran itu homonimi atau polisemi. kemungkinan-kemungkinan jawaban itu dapat berupa (1) penelusuran etimologi; jika ditemukan ujaran itu berasal dari dua sumber yang berbeda, maka ujaran itu dianggap sebagai homonimi; dalam kamus ujaran itu diperlakukan sebagai dua entri; sedangkan jika tidak ditemukan sumber yang berbeda atau berasal dari satu sumber (walaupun maknanya berbeda), ujaran itu diperlakukan sebagai polisemi; (2) kemungkinan kedua ialah penelitian apakah ujaran dan bentuk kata itu dipergunakan dalam makna harfiahnya dan dalam makna metaforis; dalam hal ini kita akan dapat meramalkan polisemi daripada homonimi; (3) usaha yang ketiga untuk menentukan polisemi atau homonimi ialah mencari sebuah makna inti; memang sulit untuk menentukan makna inti dan makna bukan inti; (4) usaha yang keempat ialah melakukan uji ambiguitas (kedwimaknaan). 


\section{Kelas Kata}

Kridalaksana (1986) menggolongkan kelas kata menjadi tiga belas, yaitu

(1) Verba

Verba merupakan kategori yang dalam tataran frasa dapat dinegatifkan dengan kata tidak dan tidak dapat didampingi kata itu, di, ke, dari, agak, lebih, atau sangat. Verba dibedakan menjadi beberapa bentuk menurut dasar yang berbeda.

(a) Jika dilihat dari bentuknya, verba dibedakan menjadi verba dasar dan verba turunan.

(b) Jika dilihat dari banyaknya pendamping verba, verba dibedakan menjadi verba intransitif dan verba transitif

(c) Jika dilihat dari hubungannya dengan nomina, verba dibagi menjadi verba, aktif, verba pasif, verba antiaktif (ergatif), dan verba antipasif.

(d) Jika dilihat dari interaksi antara nomina dan pendampingnya, verba dibedakan menjadi verba resiprokal dan verba nonresiprokal

(e) Berdasarkan sudut referensi pendamping verba, verba dibagi menjadi verba refleksif dan verba nonrefleksi

(f) Jika dilihat dari sudut pandang hubungan identifikasi antara pendamping verbanya, verba dibedakan menjadi verba kopulatif dan verba ekuatif.

(g) Jika dilihat dari dapat tidaknya dipertentangkan dengan awalan meNdan ber-, verba verba telis dan verba atelis.

\section{(2) Adjektiva}

Adjektiva merupakan kategori yang dapat bergabung dengan kata tidak, dapat didampingi kata lebih, agak, dapat digabung dengan nomina, dapat diubah menjadi nomina jika ditambah dengan imbuhan $k e$ an. Adjektiva jika dilihat dari bentuknya dibagi menjadi adjektiva dasar, adjektiva turunan, dan adjektiva paduan leksem.
Nomina merupakan kategori yang secara sintaksis tidak dapat bergabung dengan kata tidak dan dapat didahului kata dari. Nomina berdasarkan bentuknya dibagi menjadi nomina dasar, nomina turunan, nomina paduan leksem, dan nomina paduan leksem gabungan.

\section{(4)Pronomina}

Pronomina merupakan kategori yang berfungsi untuk menggantikan nomina.Kata yang digantikan oleh pronomina disebut anteseden.

\section{(5) Numeralia}

Numeralia adalah kategori yang dapat mendampingi nomina dalam konteks sintaksis, dapat mendampingi numeralia yang lain, dan tidak dapat bergabung dengan kata tidak dan sangat. Numeralia digunakan untuk mewakili bilangan yang terdapat dalam alam di luar bahasa.

\section{(6) Adverbia}

Adverbia merupakan kategori yang dapat mendampingi adjektiva, numeralia, atau preposisi dalam kontruksi sintaksis. Adverbial dapat berupa bentuk dasar atau turunan.Bentuk turunan adverbia dibentuk dari afiksasi, reduplikasi, gabungan proses, dan gabungan morfem.

\section{(7)Interogativa}

Interogativa adalah kategori dalam kalimat interogatif yang berfungsi menggantikan sesuatu yang ingin diketahui atau ditanyakan oleh pembicara. Interogativa menurut bentuknya dibagi menjadi interogativa dasar dan interogativa turunan.

\section{(8)Demonstrativa}

Demonstrativa merupakan kategori yang berfungsi menunjukkan sesuatu di dalam maupun di luar wacana. Menurut bentuknya demonstrativa dibedakan menjadi demonstrativa dasar dan demonstrativa turunan.

(9) Artikula 
Artikula merupakan kategori yang mendampingi nomina dasar.Artikula merupakan partikel sehingga tidak berartikulasi.

\section{(10) Preposisi}

Preposisi merupakan kategori yang terletak di depan kategori lain sehingga terbentuk frasa eksosentris direktif. Preposisi dibagi menjadi tiga, yaitu preposisi dasar, preposisi turunan, dan preposisi yang berasal dari kategori lain.

(11) Konjungsi

Konjungsi merupakan kategori yang berfungsi untuk memperluas satuan lain dalam konstruksi hipotaksis dan menggabungkan satuan lain.

\section{(12) Kategori fatis}

Kategori fatis merupakan kategori yang bertugas memulai, mempertahankan, atau mengukuhkan pembicaraan antara pembicara dan lawan bicara.

\section{(13) Interjeksi}

Interjeksi merupakan kategori yang berfungsi mengungkapkan perasaan pembicara dan secara sintaksis tidak berhubungan dengan kata-kata lain dalam ujaran.

\section{METODE PENELITIAN \\ Pendekatan dan Jenis Penelitian}

Penelitian ini merupakan jenis penelitian deskriptif kualitatif dengan menggunakan pendekatan semantik. Penelitian kualitatif dengan metode deskriptif adalah penelitian yang mengidentifikasi, mengklarifikasi, menganalisis data yang telah diperoleh, dan pendeskripsiannya berupa penggambaran bahasa sebagaimana adanya (Sudaryanto, 1993). Dengan demikian, pendeskripsian data penelitian ini berupa leksikon dari bahasa Kepulauan Tukang Besi Dialek Kaledupa yang berpotensi berhomonimi. Pendekatan semantik digunakan untuk menjelaskan hubungan antarmakna dalam tiap leksikon.

\section{Sumber Data dan Jenis Data}

Sumber data penelitian ini adalah penutur asli, yakni masyarakat Kaledupa. Jenis data adalah data lisan yang diperoleh dari tuturan penutur asli bahasa Kepulauan Tukang Besi Dialek Kaledupa.

\section{Metode dan Teknik Pengumpulan Data}

Metode dalam penelitian ini adalah metode observasi. Teknik-teknik yang digunakan untuk melengkapi metode observasi tersebut antara lain. (a) teknik observasi partisipasi (participant to bservation), yaitu teknik pengumpulan data yang digunakan untuk menghimpun data penelitian melalui pengamatan dan penginderaan, peneliti benar-benar terlibat dalam keseharian responden. Sibarani (2004) metode observasi partisipasi, yakni ikut berpartisipasi dalam kegiatan yang diobservasi, dideskripsi, dan dianalisis. Stainback (dalam Sugiyono, 2010) dalam observasi partisipasi, peneliti mengamati segala kegiatan yang dikerjakan responden, mendengarkan yang mereka ucapkan, dan berpartisipasi dalam aktivitas mereka; (b) teknik rekam, yakni digunakan untuk merekam peristiwa-peristiwa yang secara potensial banyak menggunakan tuturan emosi; dan (c) teknik catat, dari hasil rekaman, data-data berupa tuturan yang diucapkan responden dicatat, selanjutnya diseleksi dan diidentifikasi.

\section{Teknik Analisis Data}

Penerapan langkah-langkah dalam teknik analisis data sebagai berikut

\section{Penyeleksian data}

Kata yang berelasi makna dalam bahasa Kepulauan Tukang Besi yang telah diperoleh dari teknik pengumpulan data diseleksi yang termasuk kata-kata yang berhomonimi dengan menggunakan teori Palmer. 
2. Pengklasifikasian dan pemaknaan data

Penggolongan data hasil seleksi diklasifikasidan melalui proses pemaknaan berdasarkan pada fokus masalah, yakni wujud kelas kata yang berhomonimi dalam bahasa Kepulauan Tukang Besi Dialek Kaledupa(teori pembagian kelas kata Kridalaksana).

Penelitian ini menggunakan beberapa instrumen, seperti catatan lapangan, alat rekam, kartu data, tabel klasifikasi, dan lembar observasi. Sementara itu, tabel klasifikasi digunakan untuk mempermudah analisis wujud kelas kata yang berhomonimi dalam bahasa Kepulauan Tukang Besi Dialek Kaledupa. Adapun tabel yang dimaksud adalah

\begin{tabular}{|l|l|l|l|l|}
\hline \multirow{2}{*}{ Data } & \multirow{2}{*}{ M1 } & \multirow{2}{*}{ M2 } & \multicolumn{2}{|c|}{ Kelas Kata } \\
\cline { 4 - 5 } & & & M1 & M2 \\
\hline & & & & \\
\hline
\end{tabular}

Catatan: M1: Makna 1 (pertama)

M2: Makna 2 (kedua)

3. Penganalisisan data

Data yang telah diklasifikasi, kemudian dianalisis dengan mendeskripsikan secara mendetail permasalahan yang terdapat dalam data yang telah dikumpulkan berdasarkan teori wujud kelas kata yang berhomonimi dalam bahasa
Kepulauan Tukang Besi Dialek Kaledupa, sebagai dasar pedoman dalam menganalisis.

\section{PEMBAHASAN}

Hasil penelitian, ditemukanwujudkelas katayang berhomonim dalam bahasa Kepulauan Tukang BesiDialek Kaledupa. Adapun bentuk kelas kata yang berhominim tersebut adalah.

\begin{tabular}{|c|l|l|}
\hline \multirow{2}{*}{ No. } & \multicolumn{2}{|c|}{ Kelas Kata } \\
\cline { 2 - 3 } & Kelas Kata 1 & \multicolumn{1}{|c|}{ Kelas Kata 2 } \\
\hline 1. & Adjektiva & Nomina \\
\hline 2. & Nomina & Nomina \\
\hline 3. & Verba & Adjektiva \\
\hline 4. & Verba & Nomina \\
\hline 5. & Nomina & Numeralia \\
\hline 6. & Verba & Verba \\
\hline 7. & Verba & Adverbia \\
\hline 8. & Partikel & Nomina \\
\hline
\end{tabular}

Untuk lebih jelasnya perhatikan penjelasan tiap kelas kata yang berhomonimi dalam bahasa Kepulauan Tukang Besi Dialek Kaledupa.

\section{a. Adjektiva Nomina}

Fenomena homonimi dalam bahasa Kepulauan Tukang Besi Dialek Kaledupa terlihat pada kata yang berkelas kata adjektiva yang berhomonim dengan kelas kata nomina.Perhatikan contoh data berikut.

\begin{tabular}{|l|l|l|l|l|}
\hline \multirow{2}{*}{ Data } & \multicolumn{1}{|c|}{ M 1 } & \multicolumn{1}{c|}{ M 2 } & \multicolumn{2}{c|}{ Kelas Kata } \\
\cline { 4 - 5 } & & & M 1 & M 2 \\
\hline Modo & Sebentar & Air laut pasang & Adjektiva & Nomina \\
\hline Songko & Ketat & Kopiah & Adjektiva & Nomina \\
\hline Nihi & Tipis & Mimpi & Adjektiva & Nomina \\
\hline
\end{tabular}

\section{Contoh 1}

(a) Modo, baraho to inte kua daoa anneho no modo

(Sebentar, jangan dulu kita pergi ke pasar karena air laut masih pasang)

(b) Te songko iso no songko ara ako tei ko'o
(Kopiah itu pasti sempit kalau untuk kamu)

(c) di nihi kuita te orunguú nihikadu, u sodo?

(dalam mimpiku saya melihatmu badanmu tipis setipis karung, kamu sakit?)

Tiga contoh di atas, terlihat adanya tiga kata yang mempunyai homoniminya 
masing-masing, yaitu modo, songko, dan nihi. Ketiga kata tersebut tergolong berhomonimi karena tiap kata itu mempunyai pertalian dua kata yang memiliki pelafalan dan penulisan yang sama, tetapi makna berbeda. Dilihat pula dari wujud kelas kata ketiga kata tersebut (modo, songko, dan nihi), dibentuk oleh kelas kata adjektiva dan kelas kata nomina.

Contoh 1 (a) terdapat dua kata modo yang digunakan dalam kalimat yang sama. Kata modo mempunyai dua arti atau makna, yakni sebentar (adjektiva) dan air laut yang pasang (nomina). Perlu diketahui bahwa dalam bahasa Kepulauan Tukang Besi terdapat bunyi huruf implosif, yakni bunyi huruf $a$ (Dosa 'utang') dan 5 (bosu 'gusi'). Bunyi implosif adalah hentian yang terjadi dengan aliran udara diisap oleh glotis. Terlihat pula pada contoh 1 (b), yakni kata songko yang memiliki dua makna, yakni kata songko I bermakna ketat (adjektiva) dan kata songko II bermakna kopiah (nomina). Hal yang sama tampak juga pada contoh 1 (c) kata yang berhomonim, yaitu kata nihi. Kata nihi mempunyai dua makna, yakni kata nihi I bermakna tipis (adjektiva) dan kata nihi II bermakna mimpi (nomina). Ketiga contoh kata di atas (modo, songko, dan nihi) masing-masing mempunyai hubungan yang bersifat dua arah. Artinya, jika kata modo yang bermakna 'sebentar' berhomonimi dengan kata modo yang bermakna 'air laut pasang', maka kata modo yang bermakna 'air laut pasang' juga berhomonimi dengan kata modo yang bermakna 'sebentar'. Jika kata modo yang bermakna 'sebentar' disebut modo I dan kata modo yang bermakna 'air laut pasang' disebut modo II, diagramnya sebagai berikut.

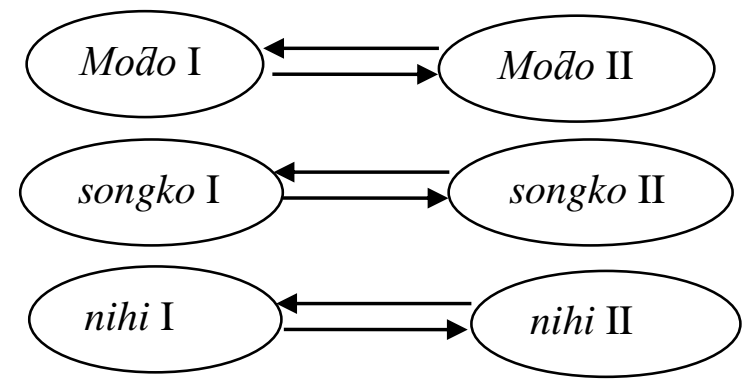

\section{b. Nomina Berhomonimi dengan Nomina}

Fenomena homonimi dalam bahasa Kepulauan Tukang Besi Dialek Kaledupa terlihat pada kata yang berkelas kata nomina yang berhomonim dengan kelas kata nomina. Perhatikan contoh data berikut.

\begin{tabular}{|l|l|l|c|c|c|c|}
\hline Data & \multicolumn{1}{|c|}{ M 1 } & M 2 & \multicolumn{2}{|c|}{ M 3 } & \multicolumn{3}{|c|}{ Kelas Kata } \\
\cline { 5 - 7 } & $\begin{array}{l}\text { Kelapa } \\
\text { yang } \\
\text { sudah tua }\end{array}$ & Mampus & - & M 1 & M 2 & M 3 \\
\hline Temba & Senapan & $\begin{array}{l}\text { Teras } \\
\text { rumah }\end{array}$ & - & Nomina & Nomina & Nomina \\
\hline Eoka & Sisa & $\begin{array}{l}\text { Telur } \\
\text { busuk }\end{array}$ & $\begin{array}{l}\text { Seserahan dari } \\
\text { seorang lelaki kepada } \\
\text { calon istrinya (berupa } \\
\text { ayam atau makanan) }\end{array}$ & Nomina & Nomina & Nomina \\
\hline
\end{tabular}

\section{Contoh 2}

(a) Ifa di atué, bara bo'ua norahokko te poso atué maka uposo (pindah di situ nanti kamu dijatuhi sama kelapa tua itu, kamu mampus itu)

(b) Intealaé na temba di temba

(pergi ambil senapan di teras) 
(c) Ragamo tegoraú boka na no boka kita

(tinggal telur busuk yang dia sisakan kita)

Contoh 2 (a) terdapat dua kata poso yang digunakan dalam kalimat yang sama. Kata poso mempunyai dua makna, yakni poso I yang bermakna kelapa yang sudah tua (nomina) dan poso II yang bermakna mampus (nomina), termasuk homonimi karena antara kata poso I dan kata poso II tidak memiliki hubungan makna.Terlihat pula pada contoh 2 (b), yakni kata temba yang memiliki dua makna, yakni temba I yang bermakna senapan (nomina) dan temba II yang berarti teras rumah (nomina). Kata temba termasuk homonimi karena antara temba I dan temba II tidak mempunyai hubungan makna. Hal yang sama tampak juga pada contoh 2 (c) kata yang berhomonimi, yaitu kata boka. Kata 5oka mempunyai tiga makna, yakni boka I yang bermakna sisa (nomina), boka II yang bermakna telur busuk (nomina), dan Eoka III yang berarti seserahan seorang lelaki kepada calon istrinya yang bisa berupa ayam atau makanan (nomina). Kata boka termasuk homonimi karena antara kata boka I, boka I, dan boka III tidak memiliki hubungan makna.

\section{c. Verba Berhomonimi dengan Adjektiva}

Homonimi dalam bahasa Kepulauan Tukang Besi Dialek Kaledupa terlihat pula pada kata yang berkelas kata verba yang berhomonimi dengan kelas kata adjektiva. Perhatikan contoh data berikut.

\section{Contoh 3}

\begin{tabular}{|l|l|l|l|l|}
\hline Data & \multicolumn{1}{|c|}{ M 1 } & \multicolumn{1}{c|}{ M 2 } & \multicolumn{2}{|c|}{ Kelas Kata } \\
\cline { 4 - 5 } & & & M 1 & M 2 \\
\hline Buri & Tulis & Warna belang & Verba & Adjektiva \\
\hline Pake & Pakai & Sikap/karakter & Verba & Adjektiva \\
\hline
\end{tabular}

(a) Anne kuburi di kapeo, nomai na mia mosafu tekadole kene kadola buri mia atu'e

(saya masih menulis kemarin, datang orang yang menyabung ayam dengan ayam belang-belang itu)

(b) Pake'e na pake leama kua mia (pakailah sikap yang baik kepada orang lain)

Contoh 3 (a) terdapat dua kata buriyang digunakan dalam kalimat yang sama. Kata buri mempunyai dua makna, yakni kata buri I bermakna tulisyang berkelas kata verba dan kata buri II yang bermakna warna belang-belang yang berkelas kata adjektiva. Kata buripada contoh kalimat di atas termasuk homonimi karena antara kata buri I dan buri II tidak memiliki hubungan makna. Pada contoh 3 (b), yakni kata pake yang memiliki dua makna, yakni kata pake I bermakna pakai yang berkelas kata verbadan kata pake II bermakna sikap/karakter yang berkelas kata adjektiva. Kata pake termasuk homonimi karena antara kata pake I dan kata pake II tidak memiliki hubungan makna.

\section{d. Verba Berhomonimi dengan Nomina}

Homonim dalam bahasa Kepulauan Tukang Besi Dialek Kaledupa terlihat pula pada kata yang berkelas kata verba yang berhomonimi dengan kelas kata nomina. Perhatikan contoh data berikut.

\section{Contoh 4}

\begin{tabular}{|c|c|c|c|c|}
\hline \multirow[t]{2}{*}{ Data } & \multirow[t]{2}{*}{ M1 } & \multirow[t]{2}{*}{ M 2} & \multicolumn{2}{|c|}{ Kelas Kata } \\
\hline & & & M 1 & M2 \\
\hline Нии́ & Beri & Pohon & Verba & Nomina \\
\hline Koho & Potong & Burung bangau & Verba & Nomina \\
\hline Tотра & Loncat/lompat & Teras rumah & Verba & Nomina \\
\hline
\end{tabular}


(beri untuk tetangga pohon itu)

(b) Koho'e na koho di singku afo (potongkan burung bangau yang ada di dapur sana)

(c) Te aeno no toppuge kaliu no tompa mina tompa nu sapono

(kakinya patah karena dia lompat dari teras rumahnya)

Contoh 4 (a) terdapat dua kata huú yang digunakan dalam kalimat yang sama. Kata huú mempunyai dua makna, yakni kata huú I beri (verba)dankata huú II bermakna bermakna pohon (nomina).Kata huú termasuk homonimi karena antara kata huú I dan kata hии́ II tidak memiliki hubungan makna. Terlihat pula pada contoh 4 (b), yakni kata koho yang memiliki dua makna, yakni kata koho I bermakna potong (verba) dankata koho II bermakna burung bangau
(nomina).Kata koho termasuk homonimi karena antara kata koho I dan kata koho II tidak memiliki hubungan makna. Hal yang sama tampak juga pada contoh 4 (c) kata yang berhomonimi, yaitu kata tompa. Kata tompamempunyai dua makna, yakni kata tompa I bermakna lompat/loncat (verba) dan kata tompa II bermakna teras rumah (nomina). Kata tompa termasuk homonimi karena antara kata tompaI dan kata tompaII tidak memiliki hubungan makna.

\section{e. Nomina Berhomonimi dengan Numeralia}

Homonimi dalam bahasa Kepulauan Tukang Besi Dialek Kaledupa terlihat pula pada kata yang berkelas kata nomina yang berhomonimi dengan kelas kata numeralia. Perhatikan contoh data berikut.

\section{Contoh 5}

\begin{tabular}{|l|l|l|l|l|}
\hline Data & \multirow{2}{*}{ M 1 } & \multicolumn{1}{c|}{ M 2 } & \multicolumn{2}{c|}{ Kelas Kata } \\
\cline { 4 - 5 } & & & M 1 & M 2 \\
\hline Lima & Tangan & Angka lima & Nomina & Numeralia \\
\hline dua & Penjolok & Angka dua & Nomina & Numeralia \\
\hline Sia & Lerai & Angka sembilan & Nomina & Numeralia \\
\hline
\end{tabular}

(a) di limaú mo na kenta lima kau di iso?

(sudah kamu pegang ikan lima ekor di sana?)

(b) Ku'ada te đua anaé, kudumua te lemo dodua iso

(saya pinjam penjolok ini, saya mau jolok dua buah lemon sana)

(c) No siate yeé, na mia sia mia atu baái?

(mereka lerai siapa, sembilan orang tadi?)

Contoh 5 (a) terdapat dua kata lima yang digunakan dalam kalimat yang sama. Kata lima mempunyai dua makna, yakni kata lima I bermakna tangan (nomina)dan kata lima II bermakna angka lima (numeralia). Terlihat pula pada contoh 5 (b), yakni kata $a u a$ yang memiliki dua makna, yaitu kata dua I bermakna penjolok (nomina) dankata dua II bermakna angka dua (numeralia). Hal yang sama tampak juga pada contoh 5 (c) kata yang berhomonimi, yaitu kata sia. Kata sia mempunyai dua makna, yakni kata siaI bermakna lerai (nomina) dan kata siaII bermakna angka sembilan (numeralia).

\section{f. Verba Berhomonimidengan Verba}

Fenomena homonimi dalam bahasa Kepulauan Tukang BesiDialek Kaledupa terlihat pada kata yang berkelas kata verba yang berhomonimi dengan kelas kata verba. Perhatikan contoh data berikut.

\begin{tabular}{|l|l|l|l|l|}
\hline Data & \multicolumn{1}{|c|}{ M 1 } & \multicolumn{1}{c|}{ M 2 } & \multicolumn{2}{c|}{ Kelas Kata } \\
\cline { 4 - 5 } & & & M 1 & \multicolumn{1}{c|}{ M 2 } \\
\hline Ita & Jaga & Lihat & Verba & Verba \\
\hline Langke & Berangkat & $\begin{array}{l}\text { Menurunkan } \\
\text { panci dari }\end{array}$ & Verba & Verba \\
\hline
\end{tabular}


ita I bermakna lihat (verba) dan kata ita I bermakna jaga (verba). Kata ita termasuk homonimi karena antara kata ita I dan kata ita II tidak memiliki hubungan makna. Terlihat pula pada contoh 5 (b), yakni kata langke yang memiliki dua makna, yakni kata langke I bermakna berangkat (verba) dan

\section{Contoh 6}

(a) U ita'e namia u mitate kenta di ana baái?

(kamu lihat orang yang jaga ikan di sini tadi?)

(b) Ara boua kulangke ilange, langke'e na kekeru mina di dalika.

(kalau saya berangkat besok, turunkan panci dari tungku)

Contoh 6 (a) terdapat dua kata ita yang digunakan dalam kalimat yang sama. Kata ita mempunyai dua makna, yakni kata

\section{Contoh 7}

\begin{tabular}{|l|l|l|c|c|}
\hline Data & M 1 & \multicolumn{1}{|c|}{ M 2 } & \multicolumn{2}{|c|}{ Kelas Kata } \\
\cline { 4 - 5 } & & & M 1 & M 2 \\
\hline Pisi & Pencet/tekan & Sangat & Verba & adverbia \\
\hline
\end{tabular}

(a) Pisié mempisi na tombolno atué (pencet dengan keras tombolnya itu)

Contoh 7 (a) terdapat dua kata pisiyang digunakan dalam kalimat yang sama. Kata pisi mempunyai dua makna, yakni kata pisi I bermana pencet/tekan (verba) dan kata pisi II bermakna sangat (adverbia). Kata pisi termasuk homonimi karena antara kata pisi I dan kata pisi II tidak memiliki hubungan makna.

\section{h. Patikel Berhomonimidengan Nomina}

Dalam bahasa Kepulauan Tukang Besi Dialek Kaledupa fenomena homonimi terlihat pula pada kata yang berkelas kata partikel yang berhomonimi dengan kelas kata nomina. Perhatikan contoh data berikut.

\section{Contoh 8}

\begin{tabular}{|l|l|l|l|l|}
\hline Data & \multicolumn{1}{|c|}{ M 1 } & \multicolumn{1}{c|}{ M 2 } & \multicolumn{2}{c|}{ Kelas Kata } \\
\cline { 4 - 5 } & & & \multicolumn{1}{c|}{ M 1 } & M 2 \\
\hline Kene & Dengan & Teman & Partikel & Nomina \\
\hline Ara & Kalau & Arak & Partikel & Nomina \\
\hline Mia & Yang & Orang & Partikel & Nomina \\
\hline
\end{tabular}

(a) di nggafi kufila-fila kenekene. (kemarin saya jalan-jalan dengan teman)

(b) Ara di iso anne na ara?

(kalau di sana ada minuman arak?)

(c) Sai leama mia nosannaa na mia (bersikap baik yang membuat orang senang)

Contoh 8 (a) terdapat dua kata kene yang digunakan dalam kalimat yang sama. Kata kene mempunyai dua makna, yakni kata kene I bermakna dengan 
(partikel)dankata kene I bermakna teman (nomina).Kata kene termasuk homonimi karena antara kata kene I dan kata kene II tidak memiliki hubungan makna.Terlihat pula pada contoh 8 (b), yakni kata ara yang memiliki dua pertalian makna, yakni kata ara I bermakna kalau (partikel) dankata ara II bermakna arak (nomina). Kata ara termasuk homonimi karena antara kata araI dan kata ara II tidak memiliki hubungan makna. Hal yang sama tampak juga pada contoh 8 (c) kata yang berhomonimi, yaitu kata mia. Kata mia mempunyai dua makna, yakni kata mia I bermakna yang (partikel) dan kata mia II bermakna orang (nomina). Kata mia termasuk homonimi karena antara kata mia I dan kata mia II tidak memiliki hubungan makna.

\section{PENUTUP}

Berdasarkan hasil penelitian pada pembahasan, penulis dapat menarik kesimpulan sesuai dengan tujuan penelitian, yaitu wujud kelas kata yang berhomonimi dalam bahasa Kepulauan Tukang Besi Dialek Kaledupa terdapat delapan kelas kata yang saling berhomonimi antara lain:

1. Terdapat kelas kata adjektiva yang berhomonimi dengan kelas kata nomina.

2. Kelas kata nomina yang berhomonimi dengan kelas kata nomina.

3. Kelas kata verba berhomonimi dengan kelas kata adjektiva.

4. Kelas kata verba berhomonimi dengan kelas kata nomina.

5. Kelas kata nomina berhomonimi dengan kelas kata numeralia.

6. Kelas kata verba berhomonimi dengan kelas kata verba.

7. Kelas kata verba berhomonimi dengan kelas kata adverbia.

8. Partikel berhomonimi dengan kelas kata nomina.

\section{DATAR PUSTAKA}

Aminuddin. 2008. Semantik: Pengantar Studi Tentang Makna. Bandung: Sinar Baru Algesindo.
Chaer, Abdul. 1997. Semantik Bahasa Indonesia. Jakarta: Depdikbud.

Chaer, Abdul dan Leonie Agustina.1995. Sosiolinguistik Perkenalan Awal. Jakarta: Rineka Cipta.

Djajasudarma, Fatimah. 2009. Semantik 1: Makna Leksikal dan Gramatikal. Bandung: Refika Aditama.

Djamudi, Nadir La. 2009."Deskripsi Fonem

Bahasa Kaledupa di

KepulauanTukang Besi

Kabupaten Wakatobi" Jurnal Kandai, Vol.5 No. 2 November 2009, ISSN 1907-204X) 2017.“Sistem Reduplikasi Bahasa KepulauanTukang Besi Dialek Kaledupa Kabupaten Wakatobi” Jurnal Totobuang, Vol.5 No 1Juni 2017)

Keraf, Gorys. 2009. Diksi dan Gaya Bahasa. Jakarta: PT Gramedia Pustaka Utama.

Kridalaksana, Harimurti. 1986. Beberapa Prinsip Perpaduan Leksem. Yogyakarta: Kanisius.

Kridalaksana, Harimurti. 2001. Kelas Kata dalam Bahasa Indonesia. Jakarta: Gramedia.

Lyons, John. 1968. Introduction to Theoritical Linguistics. Cambridge: The University Printing House.

Nur, Wa Ode Salmiani. 2015. "TipeTipeSemantik Bahasa Kepulauan Tukang Besi Dialek Kaledupa". Jurnal Humanika. No. 15 Vol. 3 Desember2015.ISSN 1979-8296.

Palmer, F.R. 1981. Semantics.Cambridge: University Press.

Parera, J.D. 1990. Teori Semantik. Jakarta: Erlangga.

Rafiati. 2016. "Preposisi Bahasa Kepulauan Tukang Besi Dialek Kaledupa". Jurnal Humanika. No. 16 Vol. 1 Maret 2016.ISSN 1979-8296.

Sibarani, Robert. 2004. Antropolinguistik: Antropologi Linguistik, Linguistik Antropologi. Medan: Poda.

Sudaryanto.(1993). Metode dan Aneka Teknik Analisis Bahasa. 
Homonim Bahasa Kepualauan .... (Susiati)

Yogyakarta: Duta Wacana

University Press.

Sugiyono.(2010). Metode Penelitian

Kuantitatif Kualitatif dan RND. Bandung: Alfabeta.

Suparmin, dkk. 2014. Bahasa dan Sastra

Indonesia Peminatan Ilmu

Bahasa dan Budaya. Surakarta: Mediatama.
Suparni.1988. Penuntun Pelajaran Bahasa dan Sastra Indonesia. Bandung: Genica.

Sutedi,Dedi. 2003. Dasar-dasar Linguistik Bahasa Jepang. Bandug: Humaniora Utama Press.

Verhaar, J.W.M. 1978. Pengantar LinguisticJilid I. Yogyakarta. Gadjah Mada Universiti Press. 